\author{
О. Г. Черников, В. С. Черный, С. В. Займагов \\ ФГБВОУ ВО «Военно-медицинская академия имени С. М. Кирова» МО РФ, г. Санкт-Петербург, Россия
}

\title{
MODERN TRENDS IN THE DEVELOPMENT OF VESSELS FOR MEDICAL PURPOSES
}

\author{
O. G. Chernikov, V. S. Cherniy, S. V. Zaymagov \\ S. M. Kirov Military Medical Academy the Russian Defense Ministry, Saint Petersburg, Russia
}

Резюме. Госпитальные суда (ГС) рассматриваются как подвижные многопрофильные лечебные организации на морском театре военных действий (ТВД). В то же время ГС используются в повседневных условиях: для медицинского обеспечения личного состава корабельных групп сил флота в дальней морской и океанской зонах; нефтяников, промысловиков, рыбаков и т. д.; в отдаленных районах побережья и на островных территориях. Проанализированы формы и способы использования ГС в соответствии с современными требованиями с учетом модернизации и развития флота (11 рис., библ.: 13 ист.).

Ключевые слова: Военно-морской флот, госпитальное судно, медицинское обеспечение, эвакуация раненых.

В соответствииснациональнойморскойполитикой Российской Федерации (РФ) предусматривается создание благоприятных условий, способствующих развитию и поддержанию флота и морской инфраструктуры на уровне, гарантирующем экономическую независимость и безопасность государства, освоение ресурсов Мирового океана и прибрежного шельфа. Поддержание условий для обеспечения защиты национальных интересов осуществляется отечественным флотом путем обеспечения военноморского присутствия и демонстрации флага РФ в Мировом океане. Для достижения этих целей на отдельных направлениях предусматривается использование корабельных группировок, медицинское обеспечение которых традиционно осуществляют ГС.

В последние годы произошли существенные изменения во взглядах на применение корабельных группировок Военно-морского флота, а также на их медицинское обеспечение. В настоящее время возникла необходимость проанализировать формы и способы использования ГС в соответствии с современными требованиями.

Необходимость оказания медицинской помощи больным и раненым на кораблях и корабельных соединениях появилась с возникновением и развитием в XVIII в. регулярного флота. Медицинская служба кораблей по своему составу и с учетом уровня развития медицины того времени принципиально была готова лечить раненых и больных на
Summary. Hospital vessels are considered as the mobile multidisciplinary medical organizations on the sea battlefield. At the same time hospital vessels are used in daily conditions: for medical support of staff of ship groups of forces of the fleet in distant sea and ocean zones; for medical support in the remote areas of the coast and island territories; for medical support of oil industry workers, field men, fishermen, etc. Forms and ways of use of hospital courts according to modern requirements, taking into account modernization and development of the fleet are analysed (11 figs, bibliography: 13 refs).

Key words: evacuation of wounded, hospital vessel, medical support, Navy

кораблях. В то же время условия размещения раненых и больных на боевых кораблях и оказание медицинской помощи были неудовлетворительными, а их большое количество снижало боеспособность корабля. В такой обстановке командование старалось максимально освободить боевые корабли от раненых, и для этой цели в состав корабельных соединений включались ГС, переоборудованные из боевых кораблей.

В дальнейшем изменялись корабли и вооружение, тактика применения сил флота, появились новые виды и рода сил (войск) флота, произошли новые открытия и достижения в технике и медицине, что в значительной степени видоизменило организацию медицинского обеспечения. Однако, несмотря на произошедшие изменения, ГС осуществляют свою деятельность в составе многих флотов мира. В настоящее время ГС имеются в составе флотов России, США, Китая, Бразилии, Индонезии, Испании, Мальты и некоторых других стран [1].

На современном этапе ГС рассматриваются как подвижные многопрофильные лечебные организации на морском ТВД. Зарубежные ГС оснащаются, как правило, госпиталем, оборудованным по классу HATO Role 3 medical facility, эквивалентным полевому госпиталю армейской дивизии, корпуса или больнице в городе с населением 25 тыс. чел. [2].

Размещение функциональных подразделений судового госпиталя на судне является стационарным, что позволяет создать наиболее благоприят- 


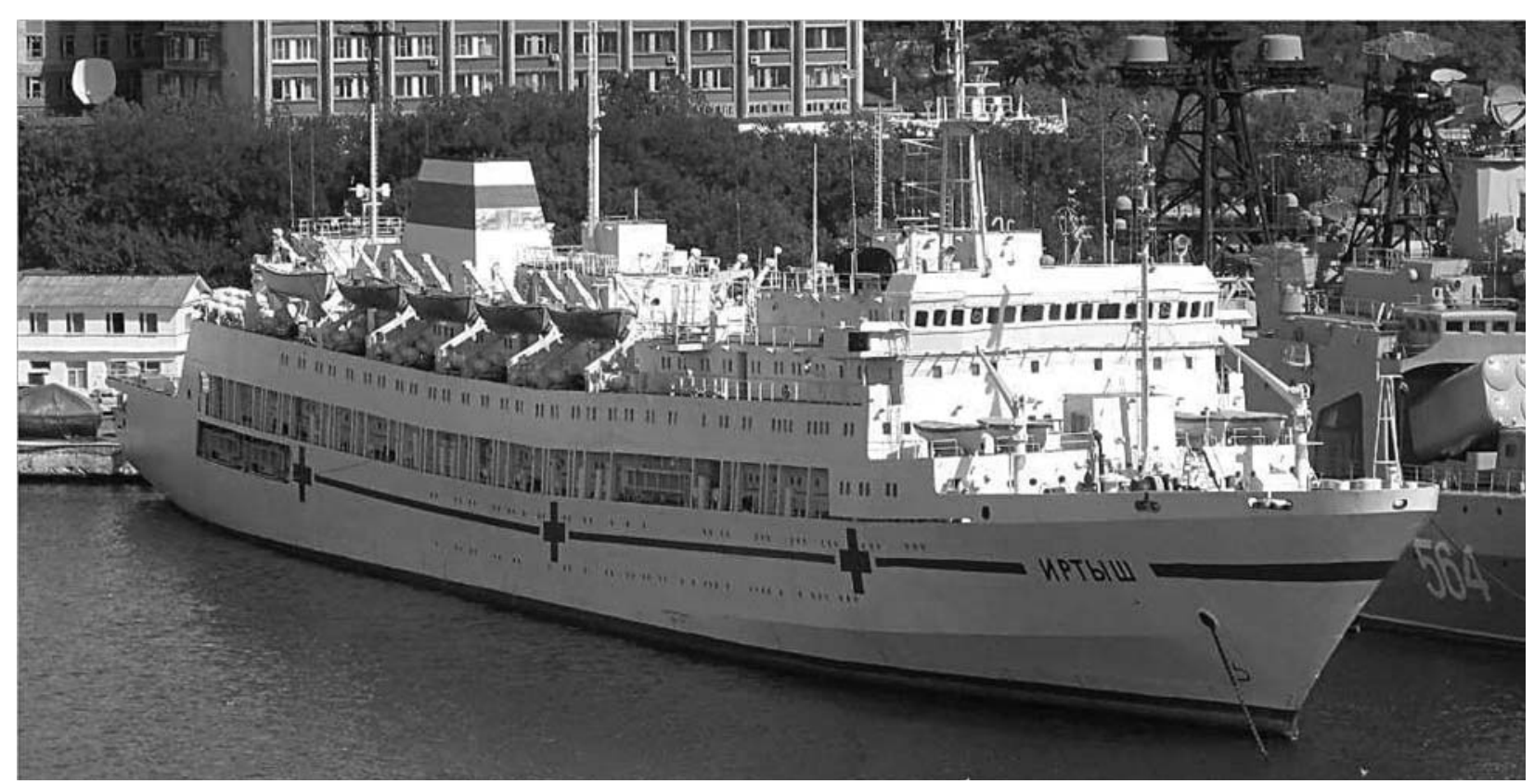

Рис. 1. ГС «Иртыш»

ные условия для работы медицинского персонала и размещения больных среди всех подвижных лечебных организаций медицинской службы.

Современные ГС имеют водоизмещение от 500 до 70 тыс. т, оборудованы, как правило, вертолетными площадками. На ГС большого водоизмещения предусматривается возможность приема тяжелых вертолетов. Вертолет является основным способом доставки раненых и больных. В обязательном порядке ГС оснащаются собственными плавательными средствами (плавсредствами): катерами и шлюпками. Корабельные средства связи на современных ГС позволяют проводить радио- и телемедицинские консультации.

Типовой состав судового госпиталя, как правило, предусматривает такие отделения, как: операционный блок на несколько операционных, реанимация, помещения для лечебно-диагностического, а именно рентгенологического, лабораторного, стоматологического и другого оборудования, размещения больных и работы медицинского персонала. На отдельных ГС предусматривается размещение мобильного полевого госпиталя и средств его перемещения.

ГС можно подразделить на суда специальной постройки и переоборудованные [3].

ГС специальной постройки состоят в составе флотов России, Китая, Испании.

Российские ГС «Енисей», «Свирь» и «Иртыш» проекта 320 - суда водоизмещением 11600 т постройки 80-х гг. XX в., на которых развернут 100-коечный судовой госпиталь (рис. 1).

ГС «Реace Ark» («Мирный ковчег») типа 920 (Китай) имеет водоизмещение 14 тыс. т, построено в 2008 г. (рис. 2). Емкость госпиталя составляет 300 коек. На ГС предусмотрено 8 операционных и 20 мест в палатах интенсивной терапии. На нем постоянно базируется тяжелый транспортный

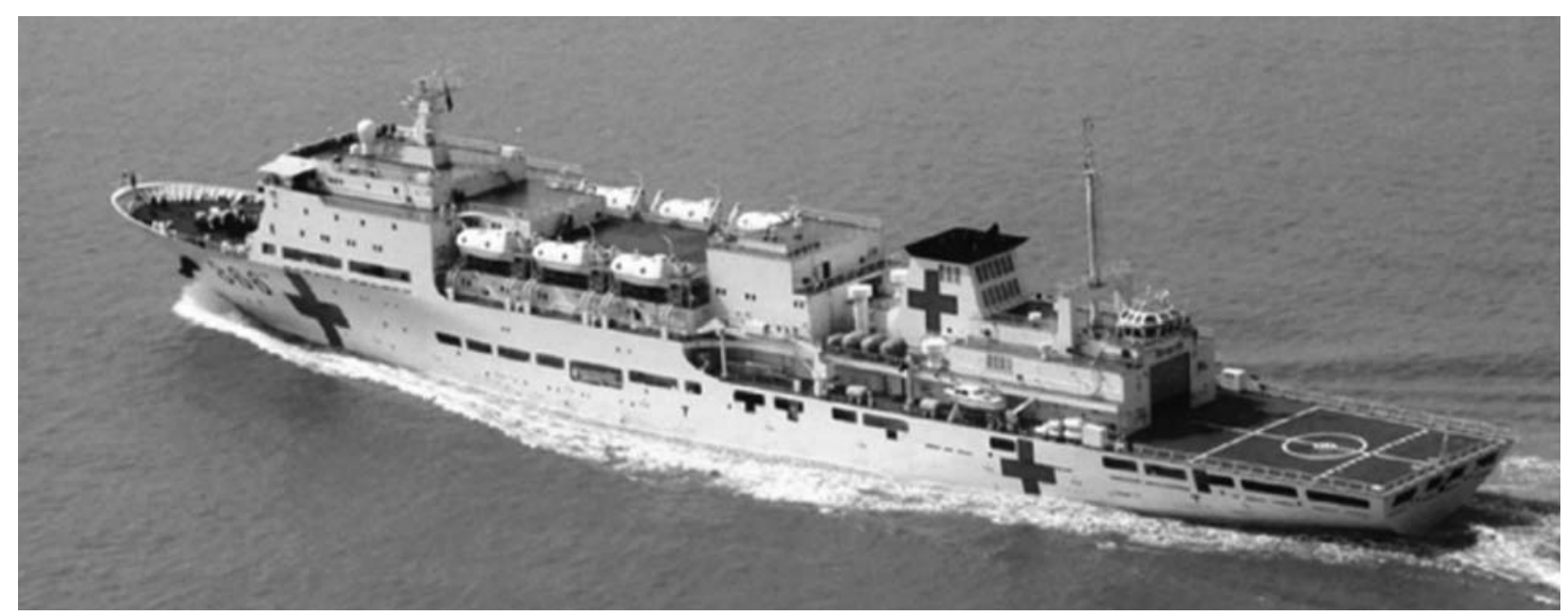

Puc. 2. ГC «Peace Ark» 


\section{HEALTH ORGANIZATION}

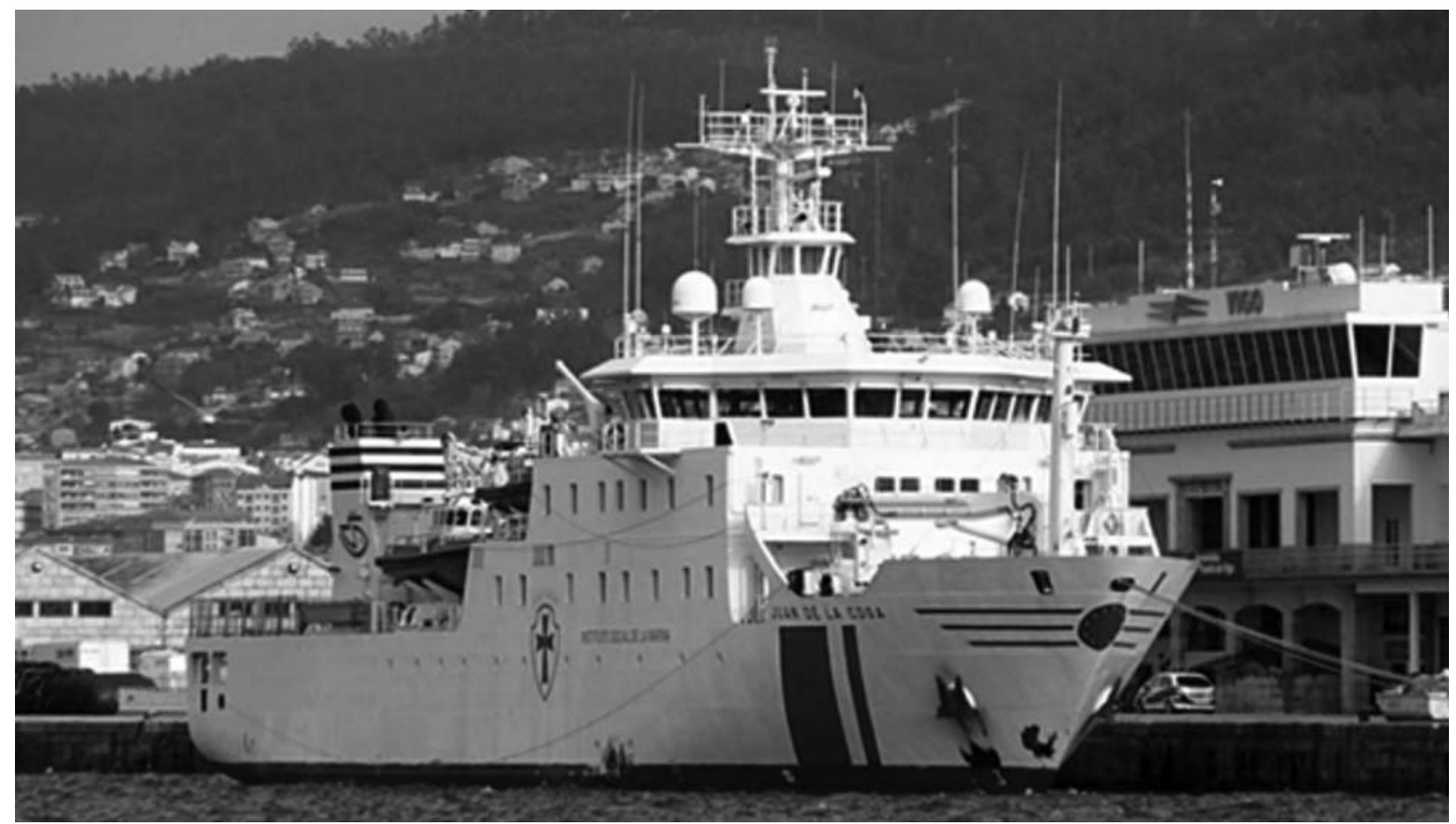

Puc. 3. ГC «Juan de la Cosa»

вертолет, способный эвакуировать до 15 носилочных больных или 27 раненых в комбинированном варианте.

ГC «Juan de la Cosa» (Испания) водоизмещением 2600 т построено в 2006 г. Судовой госпиталь рассчитан на 10 госпитальных коек, имеется отдельная зона на 12 мест для потерпевших кораблекрушение (рис. 3).

Медицинский блок судна представлен операционными, реанимационными, лабораторией, помещениями для лучевой диагностики, изолятором, вспомогательными помещениями. Радиотехническое оборудование позволяет проводить радиови- деоконференции и консультации, используя возможности телемедицины.

Все остальные суда являются переоборудованными судами торгового флота или боевыми кораблями.

ГС «Mercy» и «Comfort» (США) - танкеры класса «San Clemente», имеющие водоизмещение 70 тыс. т, построены в середине 70-х и переоборудованы в середине 80-х гг. XX в. На судне размещается 1000-коечный госпиталь, из которых 80 коек предназначены для интенсивной терапии, 20 - для послеоперационных больных, 280 - для больных средней степени тяжести, 620 коек - для больных, находящихся в удовлетворительном состоянии (рис. 4).

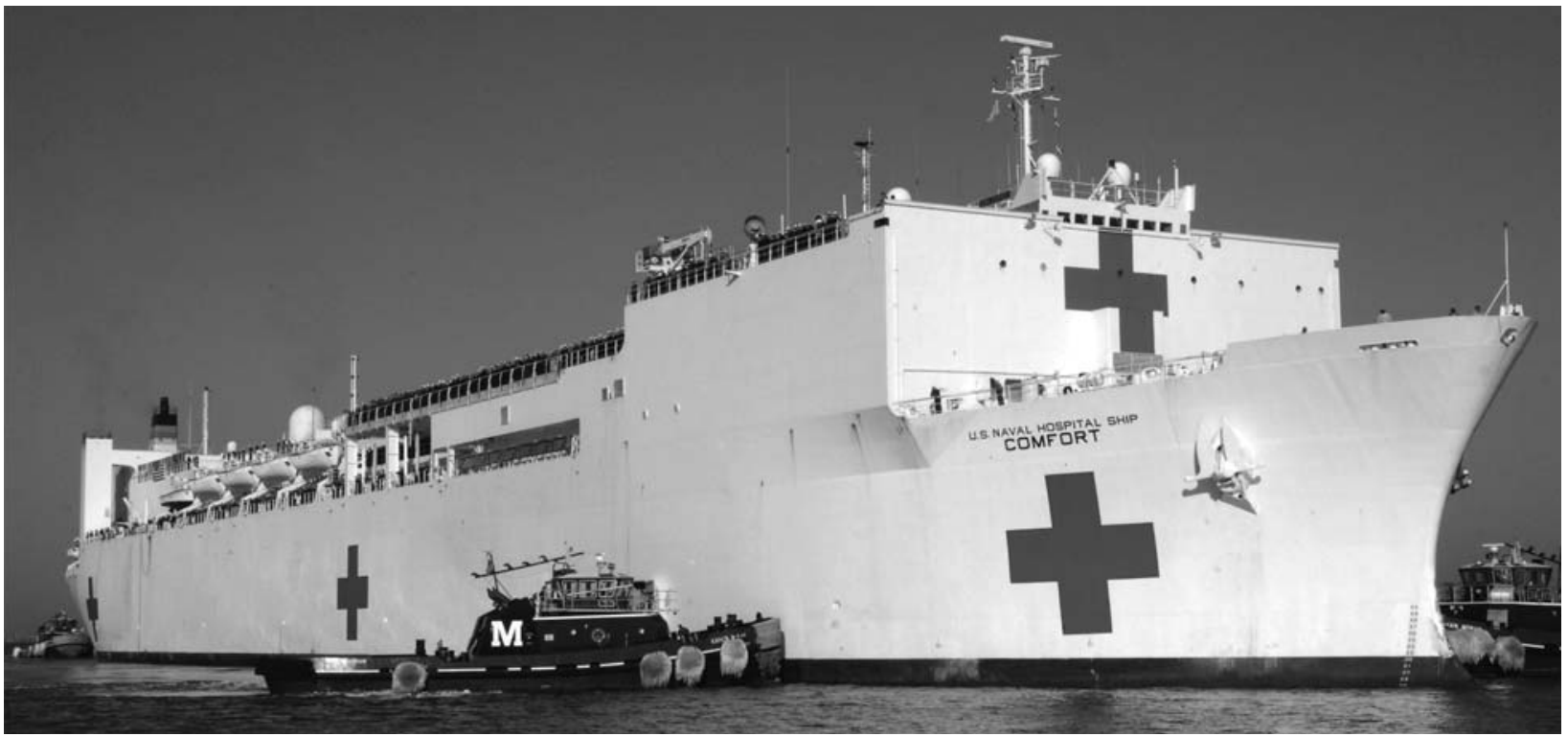

Puc. 4. ГC «Comfort» 


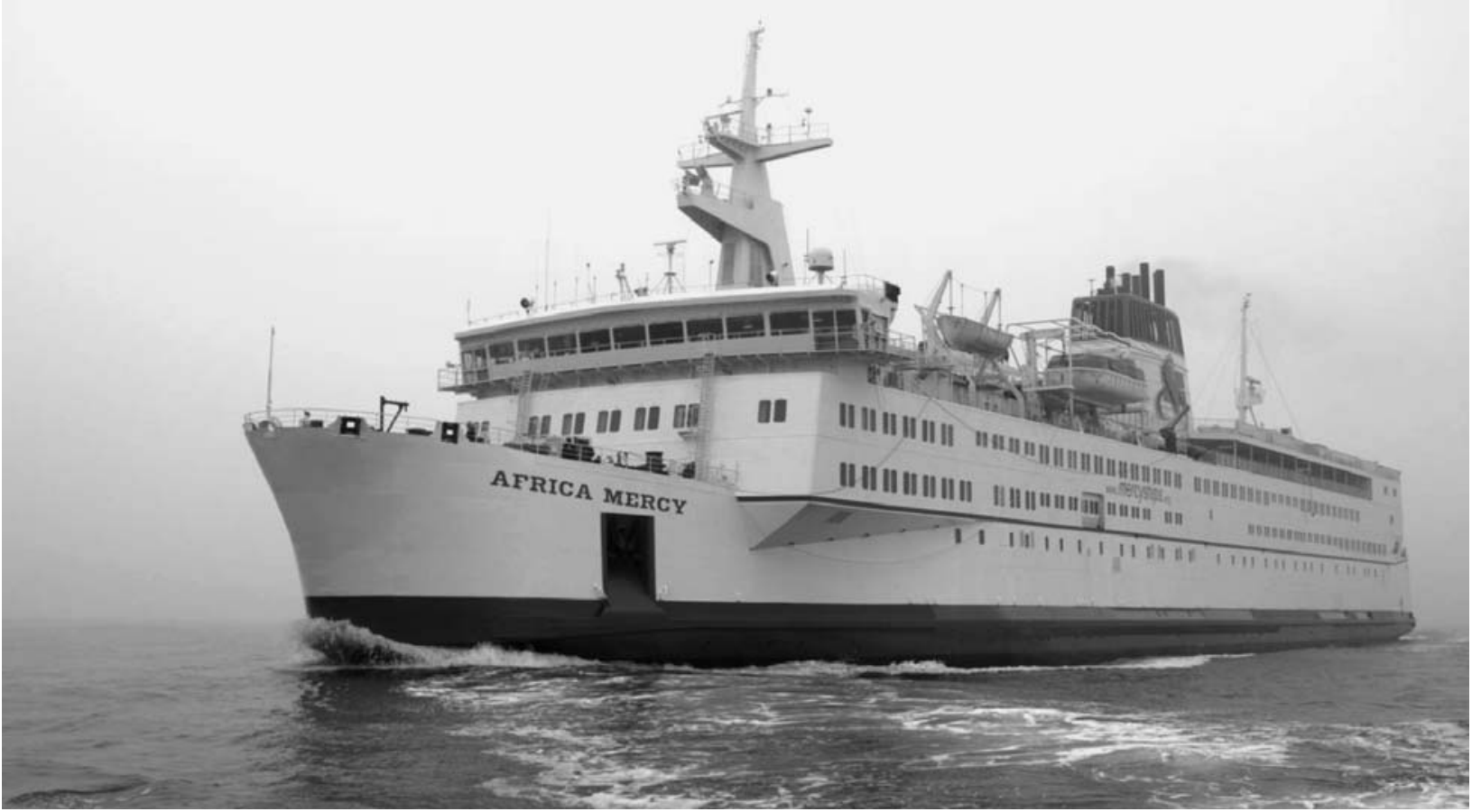

Puc. 5. ГC «Africa Mercy»

В госпитале предусмотрены 12 операционных, различные виды диагностического оборудования (для проведения томографии, ангиографии и др.). Пропускная способность составляет 200 чел. в сутки. Значительные размеры судна позволяют осуществлять посадку тяжелых вертолетов.

ГC «Africa Mercy» (Мальта) водоизмещением 16500 т переоборудовано из железнодорожного парома (рис. 5). Судовой госпиталь на 76 коек, состоит из 6 операционных, реанимации, помещений для лабораторной и инструментальной диагностики, где имеется 2 компьютерных томографа. На судне предусмотрено размещение имущества сухопутного госпиталя и 28 автомобилей для его перевозки.

ГС «Zhuanghe (Чжуанхе)» (Китай) - переоборудованный контейнеровоз постройки 1985 г. (рис. 6). Для переоборудования судна применен модульный принцип, в качестве модулей использовались стандартные морские контейнеры, содержащие необходимое медицинское и санитарное оборудование. Вместе с тем иностранные источники определяют это судно как medical evacuation ship (медицинское эвакуационное судно), в то время как остальные

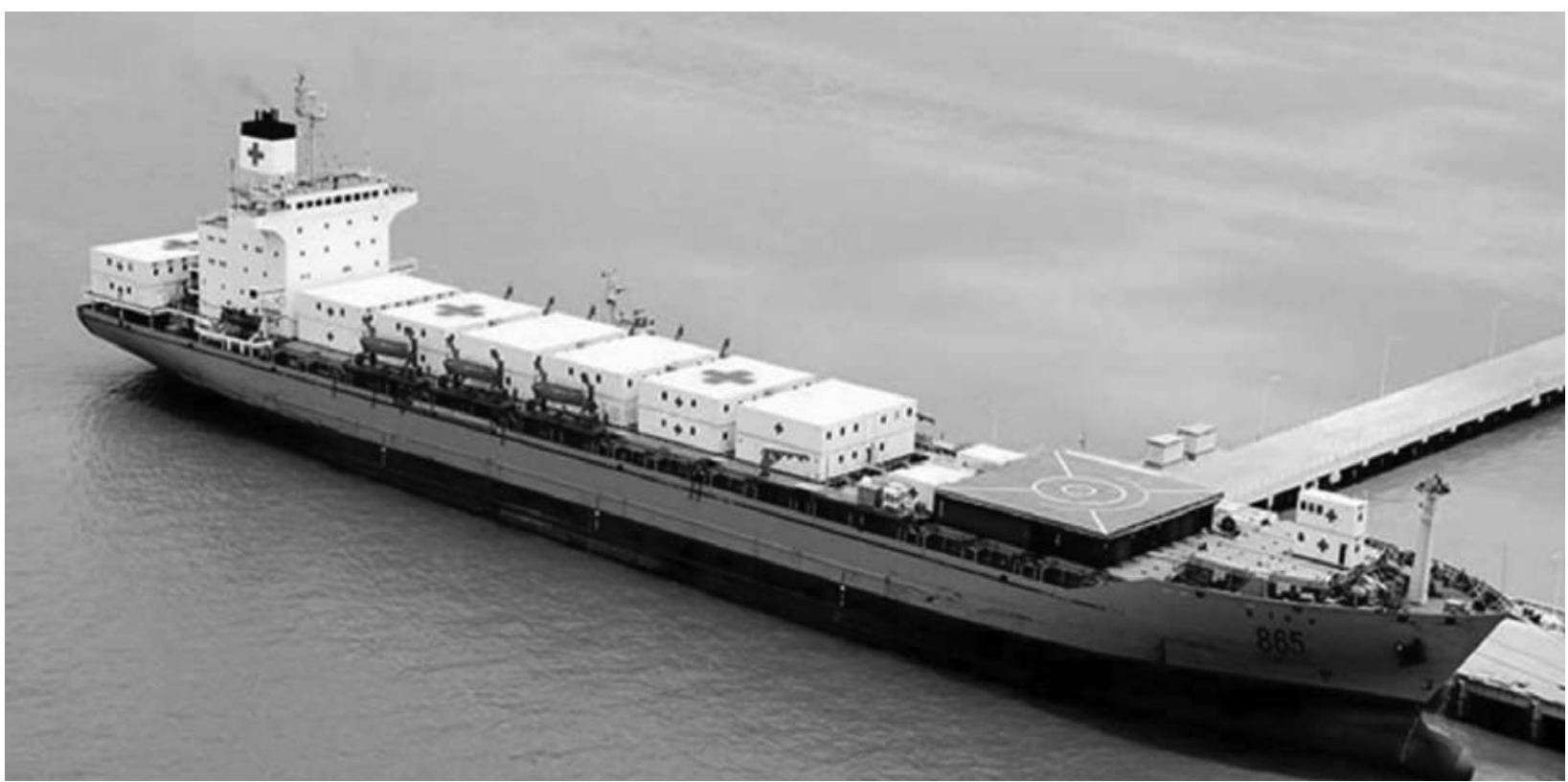

Pис. 6. ГC «Zhuanghe» 


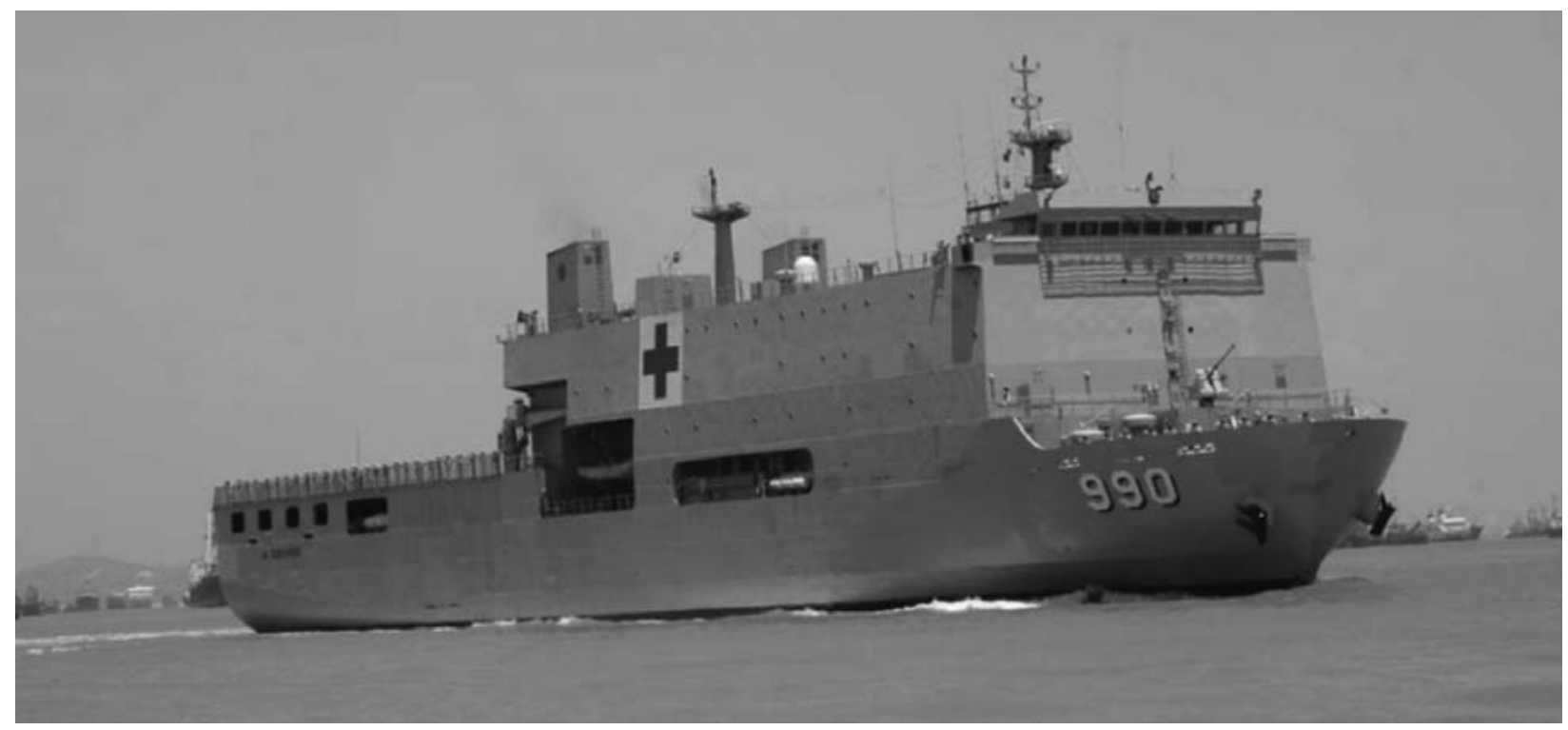

Pис. 7. ГC «Dr Soeharso»

суда - hospital ship (госпитальное судно). Сведения о результатах его использования в доступных источниках информации отсутствуют.

В отечественном кораблестроении также рассматривается вопрос создания многофункциональных модульных кораблей на основе использования типовых морских контейнеров, в том числе и медицинские модификации судов [4]. Это может обеспечить мобильность, высокую надежность, многократность использования модулей для медицинского обеспечения.

Судовые госпитали кроме ГС могут размещаться на боевых кораблях. Практически на всех кораблях с групповым базированием летательных аппаратов или док-камерами предусмотрено размещение госпиталя.

На всех универсальных десантных кораблях (УДК), имеющих док-камеру, спроектированы медицинские блоки по набору помещений, соответствующих госпиталю. На данных десантных кораблях предусматривается возможность доразвертывания на основе медицинского блока госпиталя емкостью до 600-800 коек, т. е. УДК более приспособлены для массовой эвакуации.

Достаточная вместимость УДК и наличие госпиталя позволяют привлекать такие корабли к проведению гуманитарных операций по эвакуации беженцев и т. п. Например, за один поход УДК «Mistral» в 2006 г. из Ливана было эвакуировано более 4 тыс. чел., из них около 2200 располагались в вертолетном ангаре.

По пути минимизации затрат на переоборудование корабля в ГС пошло военное руководство Индонезии. Так, ГC «Dr Soeharso» («Доктор Coехарсо») (Индонезия) с водоизмещением 16 тыс. т переоборудовали в 2007 г. из корабля-дока Makassar Class (рис. 7). Несмотря на значительные размеры, судовой госпиталь развернут на 40 коек, оборудованы
3 операционные, 6 поликлинических помещений. На судне могут быть размещены в качестве пассажиров 3 тыс. чел.

Еще один пример - медицинской блок УДК типа «Mistral» (рис. 8) [2]. По набору помещений медицинский блок соответствует госпиталю: приемно-сортировочное отделение, 2 операционные, реанимация. Помещения для работы медицинского персонала и размещения больных и оборудования расположены на площади 900 кв. м. Кроме того, при необходимости предусматривается развертывание 50 коек в ангаре.

Для более четкого понимания вопросов путей совершенствования ГС следует рассмотреть их применение.

В военное время роль ГС исключительно велика. По опыту применения в войнах и вооруженных конфликтах второй половины XX в., ГС использовались как подвижные полевые госпитали на морском ТВД для оказания квалифицированной и специализированной помощи [3, 5-8]. Совместно с ГС использовались и санитарные транспорта, осуществлявшие непосредственно эвакуацию раненых до береговых лечебных учреждений.

Так, схема лечебно-эвакуационных мероприятий в англо-аргентинском конфликте 1982 г. выглядела следующим образом: оказание медицинской помощи на берегу - доставка вертолетом раненых на ГС - оказание квалифицированной и специализированной помощи - эвакуация санитарными транспортами раненых с длительными сроками лечения на береговые аэродромы (Монтевидео) - эвакуация самолетами в лечебные учреждения Великобритании [9]. На рис. 9 представлено переоборудованное в санитарный транспорт гидрографическое судно «Herald», принимавшее участие в эвакуации раненых в районе Фолклендских островов. 


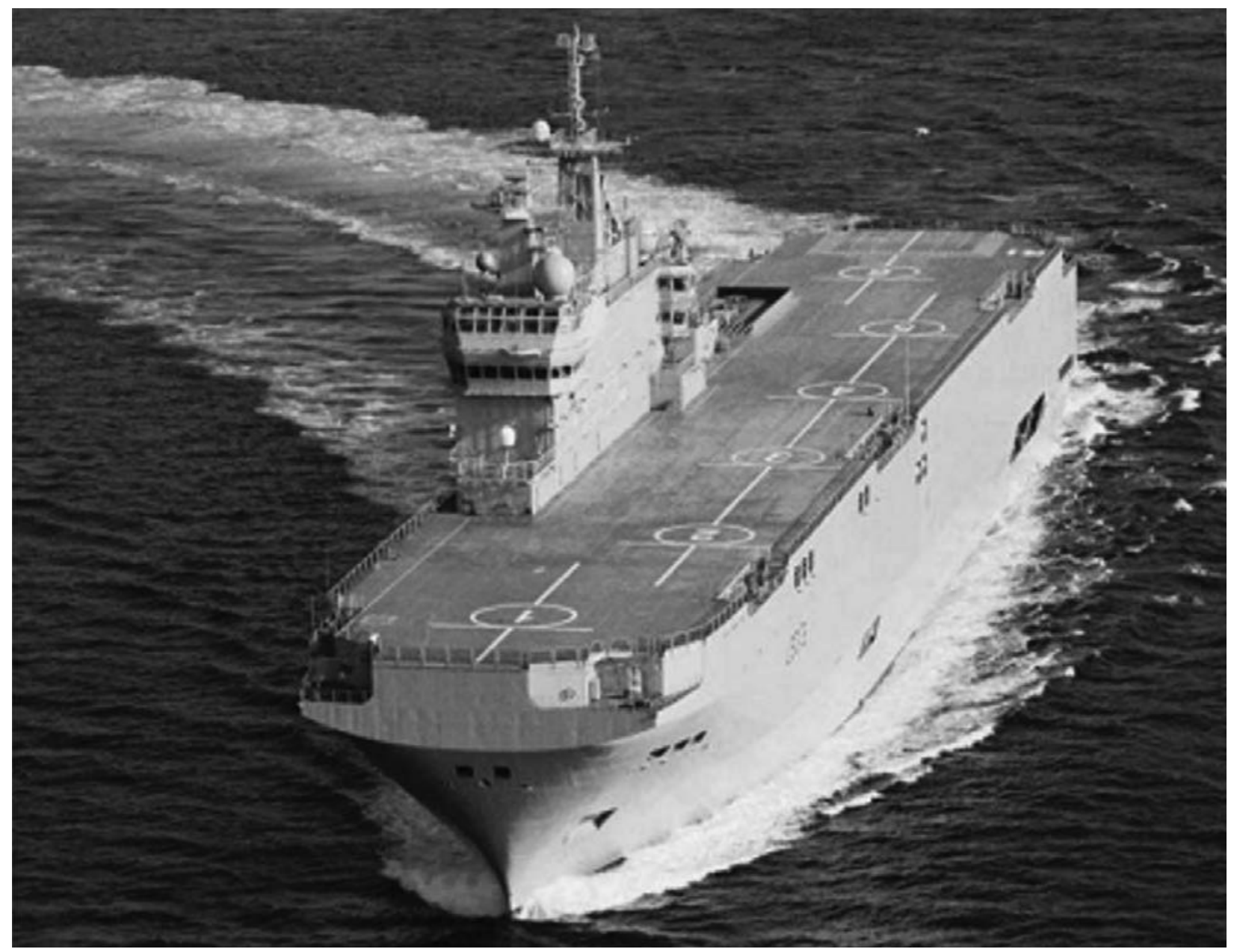

Рис. 8. УДК «Mistral»

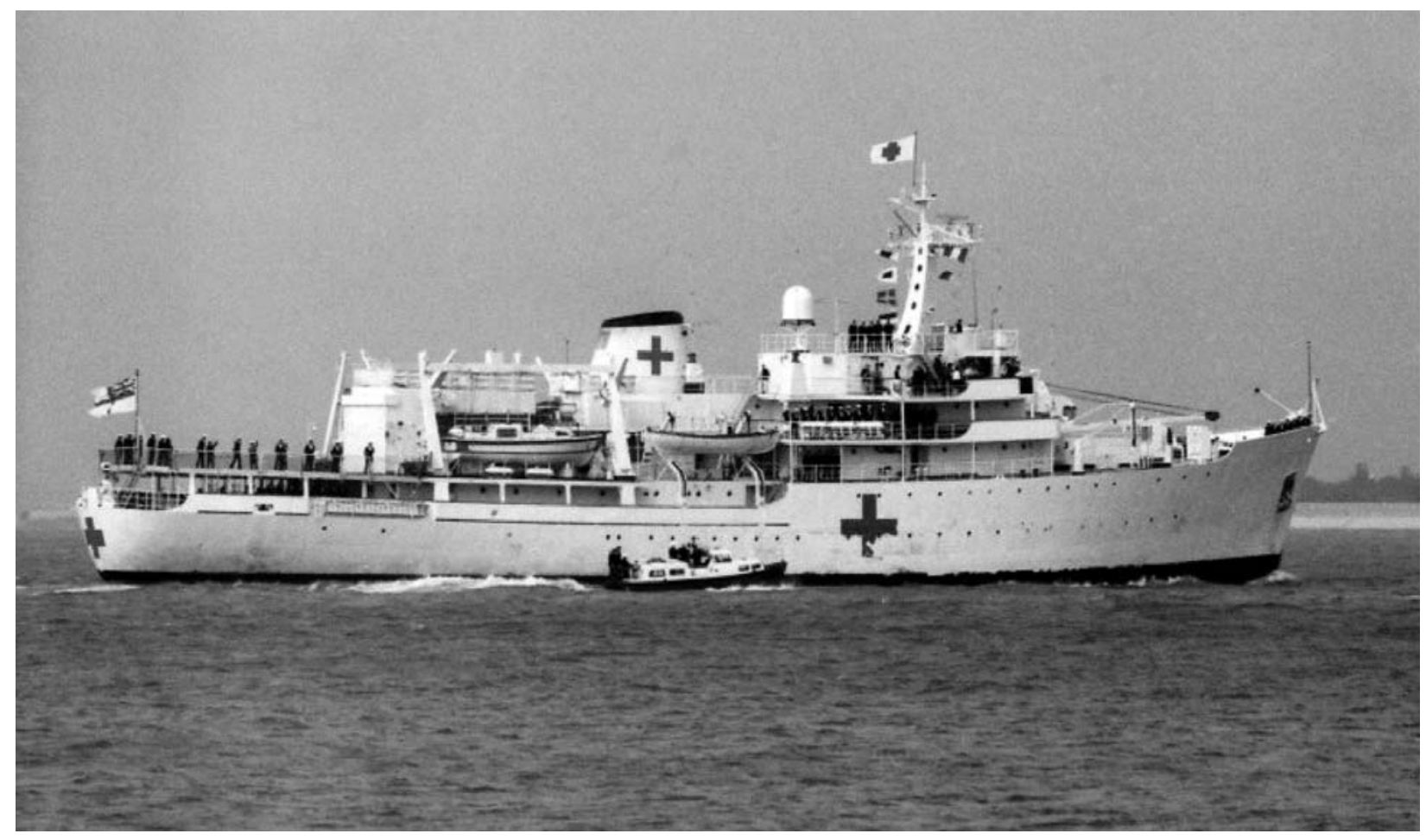

Рис. 9. Санитарный транспорт «Herald» 


\section{HEALTH ORGANIZATION}

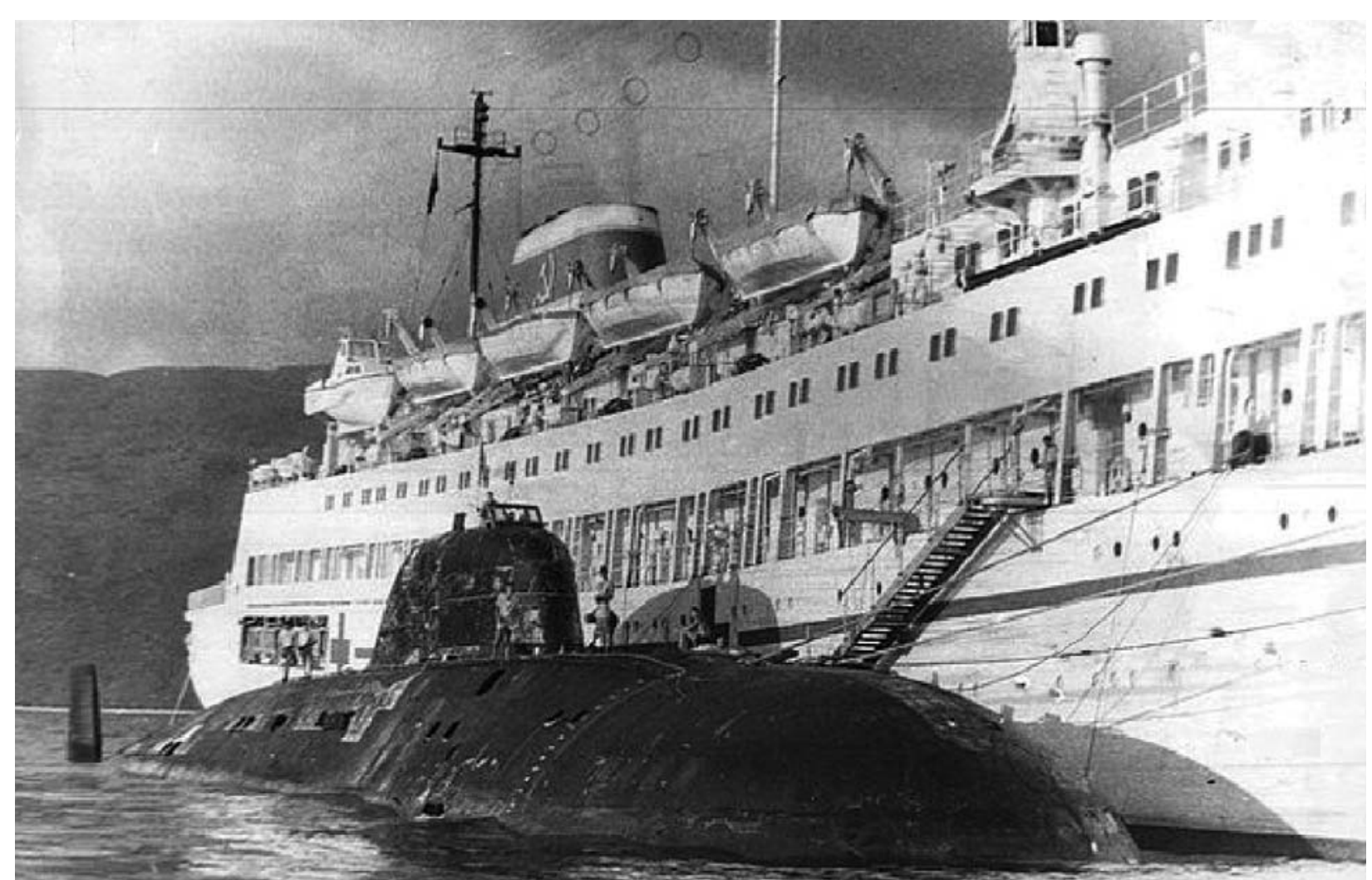

Рис. 10. Проведение профилактического отдыха личного состава экипажа дизельной подводной лодки [13]

В повседневных условиях ГС использовались: - для медицинского обеспечения личного состава корабельных групп сил флота в дальней морской и океанской зонах [3];

- для межпоходового профилактического отдыха личного состава экипажей подводных лодок [10] (рис. 10);

- для медицинского обеспечения населения в отдаленных районах побережья и островных территорий;
- для медицинского обеспечения нефтяников, промысловиков, рыбаков и т. д. [11, 12];

- для ликвидации медико-санитарных последствий чрезвычайных ситуаций [1];

- для участия в проведении гуманитарных операций (рис. 11).

Кроме того, следует отметить, что использование ГС является заметным способом демонстрации государственного флага в различных зонах Мирового океана.

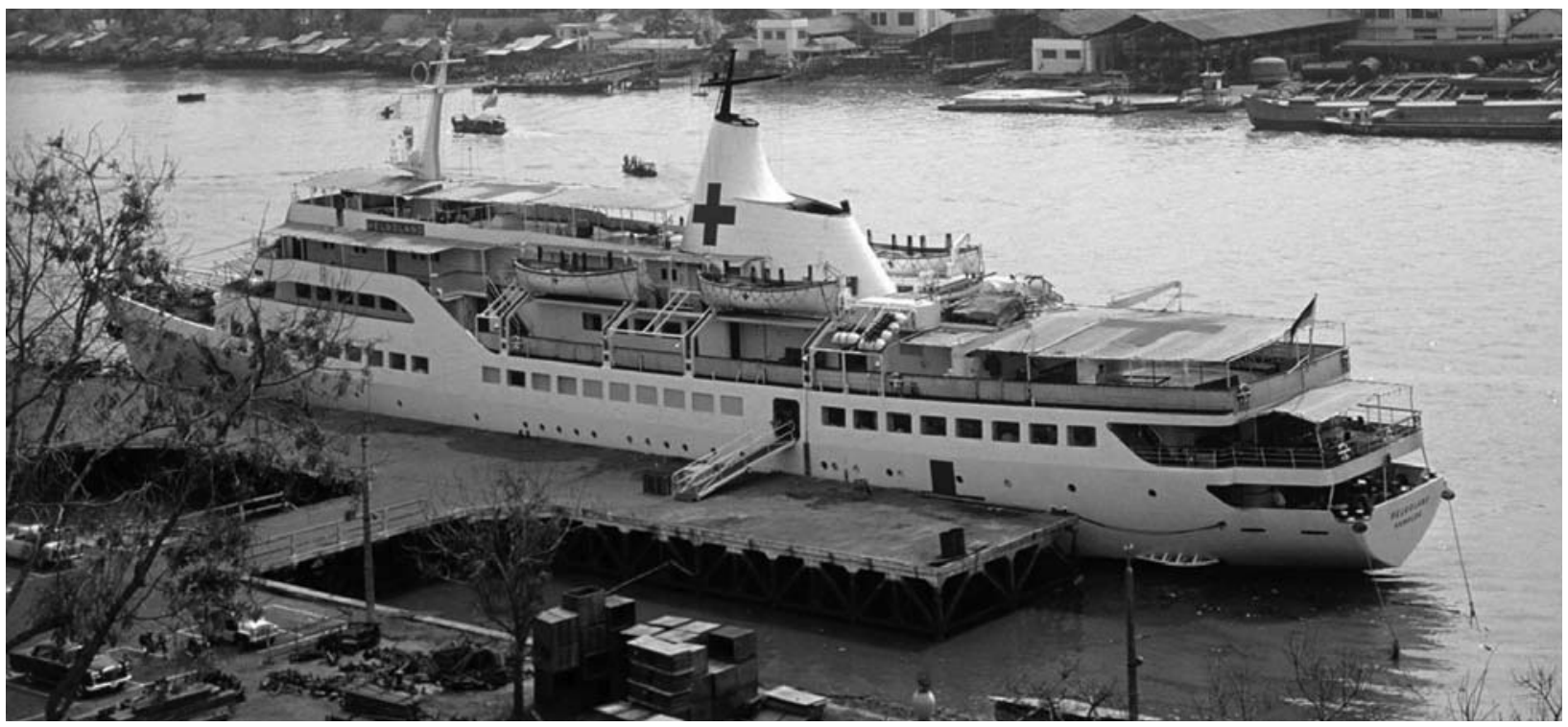

Рис. 11. ГС «Гельголанд» (ФРГ) оказывает помощь гражданскому населению, Вьетнам, 1967 г. 
Нынешние требования и стандарты оказания медицинской помощи, лечебно-диагностического сопровождения лечения вызывают необходимость обеспечения ГС современным высокотехнологичным медицинским оборудованием и техникой отечественного производства, способными работать в корабельных и морских условиях (при воздействии электромагнитных полей корабля, вибрации, волнении моря и др.).

Сложность разработки и обеспечения ГС заключается в том, что потребность в медицинской аппаратуре, отвечающей предъявляемым требованиям, является единичной (штучный товар), что не влечет за собой серийного производства, и, таким образом, данные разработки становятся малоперспективными.

Потребность в медицинской технике общеврачебного применения (аппараты ЭКГ, УЗИ и т. д.) более широки, так как подобной техникой оснащаются медицинские службы кораблей, а не только ГС.

При использовании ГС в дальней морской и океанской зонах с ограниченной береговой инфраструктурой достаточно актуальным является совершенствование средства передачи раненых (больных) с корабля на корабль в море. В современных условиях основным средством передачи раненых является вертолет, однако следует отметить, что использование вертолета не всегда возможно.

Совершенствование вопросов доставки раненых с помощью вертолетов в первую очередь должно осуществляться в направлении повышения эваковместимости, унификации медицинского оснащения вертолетов. Проблемными вопросами здесь являются: малая эваковместимость вертолетов, способных осуществлять посадку на корабли; вертолетные модули не в полной мере подходят для вертолетов корабельной авиации.

Кроме того, необходимо совершенствование судовых плавсредств как за счет приспособления имеющихся шлюпок, катеров, так и за счет разработки специальных средств для перевозки раненых.

Применение ГС в качестве многопрофильного госпиталя предполагает его длительное постоянное нахождение в районах выполнения поставленных задач, что влечет за собой необходимость эвакуации больных и раненых с длительными сроками лечения в береговые учреждения. В данном аспекте одним из направлений исследований следует считать разработку и оснащение быстроходных средств медицинской эвакуации.

Достаточно перспективным направлением является совершенствование использования судов вспомогательного флота (гражданского флота) в качестве санитарных транспортов. В последние десятилетия интерес к использованию санитарных транспортов был весьма невелик. Однако с развитием системы базирования сил флота и в случае ведения крупномасштабных действий на отдаленных морских ТВД без данной категории транспортных средств не обойтись.

В этом направлении привлекают внимание разработка и оснащение медицинских модулей на базе стандартных контейнеров. Традиционным направлением следует считать разработку санитарного оборудования для судов вспомогательного (гражданского) флота.

Вопросы медицинского обеспечения прикрепленных контингентов в отдаленных районах побережья и на островных территориях актуализируют применение санитарных катеров специальной постройки.

Значимость ГС в решении задач медицинского обеспечения была доказана в ходе выполнения задач международного учения «СМОА-плюс» стран, входящих в Ассоциацию государств Юго-Восточной Азии, которое проходило с 1 по 11 сентября 2016 г. в провинции Чонбури Королевства Таиланд и морской акватории Сиамского залива Южно-Китайского моря. В активной фазе учений были задействованы российские врачебно-сестринские бригады, которые оказывали помощь пострадавшим после условных природных бедствий. На ГС «Иртыш» Тихоокеанского флота были развернуты палаты для приема раненых и пораженных. Доставка условно пострадавших осуществлялась с помощью корабельного вертолета Ка-27 и быстроходных плавсредств.

Таким образом, на протяжении всей истории Военно-морского флота ГС остаются одной из важнейших составляющих медицинского обеспечения. В современных условиях необходимо переосмысление тактики их использования с учетом имеющихся возможностей и перспектив развития.

\section{СПИСОК ЛИТЕРАТУРЫ / REFERENCES}

1. Mosyagin I. G., Smurov A. V., Korzhov I. V., Voronov V. V. Hospital ships of foreign States. Morskoy sbornik. 2016; 2032 (7): 48-50. Russian (Мосягин И. Г., Смуров А. В., Коржов И. В., Воронов В. В. Госпитальные суда иностранных государств. Морской сборник. 2016; 2032 (7): 48-50).

2. http://wiki.wargaming.net/ru/Navy:Десантные_корабли_ типа_Mistral (10.09.16).

3. Nikitin E. A. Court medical purposes. Moscow: Voyenizdat; 1996. 295. Russian (Никитин Е. А. Суда медицинского назначения. М.: Воениздат; 1996. 295).
4. Egorov G. V., Tonuk V. I. Twelve multi-purpose dry cargo vessels with deadweight of 5500 tons of 005RSD03 project type «Russian». Sudostroyeniye. 2015; 1: 9-17. Russian (Егоров Г. В., Тонюк В. И. Двенадцать многоцелевых сухогрузных судов дедвейтом 5500 т проекта 005RSD03 типа «Россиянин». Судостроение. 2015; 1: 9-17).

5. Simonenko V. B., Abashin V. G., Aleksandrov A. S. The Russo-Japanese war of 1904-1905. Hospital ships of the 2nd Pacific squadron. Morskaya meditsina. 2015; 1 (4): 64-8. Russian (Симоненко В. Б., Абашин В. Г., Александров А. С. Рус- 
ско-Японская война 1904-1905 гг. Госпитальные суда 2-й Тихоокеанской эскадры. Морская медицина. 2015; 1 (4): 64-8).

6. Simonenko V. B., Abashin V. G., Sergoventsev A. A., Aleksandrov A. S. The death of the "merciful ships" (the 100th anniversary of the tragedy on the Black sea). Morskaya meditsina. 2016; 2 (2): 81-7. Russian (Симоненко В. Б., Абашин В. Г., Серговенцев А. А., Александров А. С. Гибель «милосердных кораблей» (к 100-летию трагедии на Черном море). Морская медицина. 2016; 2 (2): 81-7).

7. Fedotov V.V. Vessels and ships involved in the medical service of the Navy to evacuate the wounded and sick in the period of the great Patriotic war (1941-1945). Leningrad; 1989. 91. Russian (Федотов В. В. Суда и корабли, привлекающиеся медицинской службой ВМФ к эвакуации раненых и больных в период Великой Отечественной войны (1941-1945 гг.). Л.; 1989. 91).

8. Chernikov O. G., Cherniy V. S., Zabrodskiy D. S., Zaymagov S. V. On the experience of medicine of the Navy during the war. Military Medical Journal. 2015; 336 (5): 42-7. Russian (Черников О. Г., Черный В. С., Забродский Д. С., Займагов С. В. Об опыте работы медицины Военно-морского флота в годы войны. Воен.-мед. журн. 2015; 336 (5): 42-7).

\section{ИНФОРМАЦИЯ ОБ АВТОРАХ}

Черников Олег Григорьевич - канд. мед. наук, доцент, начальник кафедры организации и тактики медицинской службы флота (с курсом тактики и боевых средств флота), ФГБВОУ ВО «Военно-медицинская академия имени С. М. Кирова» МО РФ, 194044, Россия, г. Санкт-Петербург, ул. Академика Лебедева, д. 6, конт. тел.: +7(812)3297120

Черный Валерий Станиславович - докт. мед. наук, доцент, профессор кафедры организации и тактики медицинской службы флота (с курсом тактики и боевых средств флота), ФГБВОУ ВО «Военно-медицинская академия имени С. М. Кирова» МО РФ, 194044, Россия, г. Санкт-Петербург, ул. Академика Лебедева, д. 6, конт. тел.: +79119297911, e-mail: 9297911@list.ru

Займагов Сергей Владимирович - преподаватель кафедры организации и тактики медицинской службы флота (с курсом тактики и боевых средств флота), ФГБВОУ ВО «Военно-медицинская академия имени С. М. Кирова» МО РФ, 194044, Россия, г. Санкт-Петербург, ул. Академика Лебедева, д. 6, конт. тел.: $+7(812) 2923440$
9. Konovalov V. D., Batrakov T. N. Medical support of the Royal Navy in Angelegenheiten conflict. Military Medical Journal. 1987; 8: 42-47. Russian (Коновалов В. Д., Батраков Т. Н. Медицинское обеспечение ВМС Великобритании в англоаргентинском конфликте. Воен.-мед. журн. 1987; 8: 42-47).

10. Dovgusha V. V., Myznikov I. L. Stay on the stages of training and combat activities of divers. Manual for doctors of the Navy. Saint Petersburg: Press-Servis; 2010. 224. Russian (Довгуша В. В., Мызников И. Л. Отдых на этапах учебно-боевой деятельности подводников. Пособие для врачей ВМФ. СПб.: Пресс-Сервис; 2010. 224).

11. Val'skiy V. V., Grebenyuk A. N., Nosov A. V. Medical support work in areas of flooding of chemical weapons. Saint Petersburg: Yat'; 2009. 96. Russian (Вальский В. В., Гребенюк А. Н., Носов А. В. Медицинское обеспечение работ в районах затопления химического оружия. СПб.: b; 2009. 96).

12. http://www.korabli.eu/galleries/oboi/grazhdanskie-suda/ esperanza-del-mar/_(10.09.16).

13. http://forum.worldofwarships.ru/index.php?/topic/9946-\% D0\%B3\%D0\%BE\%D1\%81\%D0\%BF\%D0\%B8\%D1\%82\%D0\% B0\%D0\%BB\%D1\%8C\%D0\%BD\%D1\%8B\%D0\%B5-\%D1\%81 \%D1\%83\%D0\%B4\%D0\%B0/ (15.04.16).

\section{INFORMATION ABOUT AUTHORS}

Chernikov Oleg G. - M. D., Ph. D. (Medicine), Assoc. Prof., the Head of the Organization and Tactics of medical service of the Navy (with a course of tactics and weapons of the fleet) Department, S. M. Kirov Military Medical Academy the Russian Defense Ministry, 6, Akademika Lebedeva str., Saint Petersburg, Russia, 194044, cont. phone: $+7(812) 3297120$

Cherniy Valeriy S. - M. D., D. Sc. (Medicine), Prof., the Head of the Organization and Tactics of medical service of the Navy (with a course of tactics and weapons of the fleet) Department, S. M. Kirov Military Medical Academy the Russian Defense Ministry, 6, Akademika Lebedeva str., Saint Petersburg, Russia, 194044, cont. phone: +79119297911, e-mail: 9297911@list.ru

Zaymagov Sergey V. - Faculty of the Organization and Tactics of medical service of the Navy (with a course of tactics and weapons of the fleet) Department, S. M. Kirov Military Medical Academy the Russian Defense Ministry, 6, Akademika Lebedeva str., Saint Petersburg, Russia, 194044, cont. phone: $+7(812) 2923440$ 